\title{
PELATIHAN PERPAJAKAN PADA BADAN USAHA MILIK DESA (BUMDes) DI KABUPATEN BINTAN
}

\section{Taxation Training on "Badan Usaha Milik Desa” (BUMdes) in Bintan Regency}

\author{
Fatahurrazak $^{1 *}$, Muhammad Idris DM ${ }^{2}$ \\ ${ }^{1)}$ Jurusan Akuntansi, Fakultas Ekonomi, Universitas Maritim Raja Ali Haji, Tanjungpinang \\ 2)Jurusan Manajemen, Fakultas Ekonomi, Universitas Maritim Raja Ali Haji, Tanjungpinang \\ *Korespondensi : fatahurrazak@umrah.ac.id
}

\begin{abstract}
ABSTRAK
BUMDes sebagai usaha desa yang didirikan oleh pemerintah desa yang kepemilikan modal dan pengelolaannya dilakukan oleh pemerintah desa dan masyarakat. Seperti badan usaha lainnya, BUMDes tidak terlepas dari permasalahan perpajakan karena aktifitas yang dilakukan BUMDes sama dengan usaha lainnya di luar BUMDes. Sebagai Wajib Pajak, BUMDes berkewajiban melaksanakan pembukuan terkait kegiatan usaha yang dilakukannya karena Wajib Pajak badan di Indonesia wajib menyelenggarakan pembukuan. Terdapat beberapa pertanyaan yang sering disampaikan oleh pengurus BUMDes ke KPP atau KP2KP terkait dengan penerapan perpajakan apa saja yang harus dilaksanakan oleh BUMDes. Pelatihan perpajakan ini berusaha menjawab pertanyaan-pertanyaan pengurus BUMDes yang dilaksanakan secara daring bagi BUMDes yang ada di Kabupaten Bintan, mengingat wabah corona saat ini belum memungkinkan untuk dilakukan secara offline. Pelatihan ini dilaksanakan pada tanggal 25 Agustus 2020 yang diikuti sebanyak 30 pengurus BUMDes yang ada di Kabupaten Bintan dan sekitarnya. Pada pelatihan ini akan diberikan penjelasan dan pemahaman terkait dengan Ketentuan Umum dan Tata Cara Perpajakan, Pajak Penghasilan dan PPN.

Kata kunci : BUMDes, Pelatihan, Perpajakan
\end{abstract}

\begin{abstract}
BUMDes as a village business established by the village government whose ownership and management of capital is carried out by the village government and the community. Like other business entities, BUMDes cannot be separated from taxation problems because the activities carried out by BUMDes are the same as other businesses outside BUMDes. As a Taxpayer, BUMDes is obligated to keep books of account related to the business activities it carries out because corporate taxpayers in Indonesia are required to keep books of account. There are several questions that are often asked by BUMDes management to KPP or KP2KP related to the implementation of any taxation that must be carried out by BUMDes. This tax training seeks to answer questions from BUMDes administrators who are conducted online for BUMDes in Bintan Regency, considering that the current corona outbreak is not yet possible to do offline. This training was held on August 25, 2020, which was attended by 30 BUMDes administrators in Bintan Regency and its surroundings. This training will provide an explanation and understanding of the General Provisions and Procedures for Taxation, Income Tax and VAT.
\end{abstract}

Keyword : BUMDes, Training, Taxation 


\section{PENDAHULUAN}

\section{Analisis Situasi}

Pajak merupakan sumber anggaran pendapatan negara yang paling pokok. Perpajakan menyangkut dua masalah pokok, yaitu bagaimanakah sistem administrasi membiayai pengadaan dan penyediaan barang dan jasa kolektif yang sukar dapat disediakan melalui mekanisme pasar serta bagaimanakah membiayai program-program yang dapat menghindarkan akibat sampingan dalam mekanisme pasar.

Pajak merupakan suatu pungutan yang dipaksakan oleh pemerintah untuk berbagai tujuan, misalnya untuk membiayai penyediaan barang dan jasa publik, untuk mengatur perekonomian, dapat juga mengatur konsumsi masyarakat. Karena sifatnya yang dipaksakan tersebut maka pajak akan mempengaruhi perilaku ekonomi masyarakat atau seseorang. Pajak merupakan suatu pungutan yang dipaksakan oleh pemerintah untuk berbagai tujuan, misalnya untuk membiayai penyediaan barang dan jasa publik, untuk mengatur perekonomian, dapat juga mengatur konsumsi masyarakat. Karena sifatnya yang dipaksakan tersebut maka pajak akan mempengaruhi perilaku ekonomi masyarakat atau seseorang.

Pajak merupakan sumber penerimaan negara yang sangat penting dalam menopang pembiayaan pembangunan yang bersumber dari dalam negeri. Besar-kecilnya pajak akan menentukan kapasitas anggaran negara, baik untuk pembiayaan pembangunan maupun anggaran rutin. Pajak sebagai instrumen fiskal yang merupakan penerimaan negara kemudian menjadi suatu investasi pemerintah dan digunakan untuk memenuhi kemakmuran rakyat.

Dalam implementasinya, pemungutan pajak dapat berjalan baik bila prinsip-prinsip kebijakan perpajakan dapat diterapkan. Smith dan Jones mengemukakan tentang prinsip kebijakan perpajakan yang dikenal dengan istilah Smith's Canons. Prinsip-prinsip itu meliputi asas kesamaan (equality and equity), asas kepastian hukum (certainty), asas tepat waktu (convenice), dan asas ekonomi atau efisiensi (economy or efficiency). Jika prinsip itu diterapkan secara menyeluruh, sistem perpajakan berjalan ideal.

Dalam menjalankan kebijakan perpajakan, pemerintah di setiap negara memiliki hak yuridis secara eksklusif untuk memungut dari wajib pajak. Yurisdiksi itu tentunya berlandaskan undang-undang yang dibuat bersama dengan legislatif. Hal itu dilakukan dengan memberi batasan-batasan dari pengenaan dan besarnya pajak yang dibebankan pada subjek dan objek pajak. Atas dasar uraian itu, jelas dapat dikatakan bahwa upaya perpajakan (tax effort) melalui yurisdiksi yang jelas merupakan langkah strategis dalam upaya meningkatkan penerimaan negara dari sektor perpajakan.

Sejalan dengan adanya yurisdiksi dan kepastian hukum, kebijakan perpajakan bertujuan mendorong kemajuan ekonomi sebagai upaya peningkatan hasrat konsumsi masyarakat, meningkatkan investasi pemerintah, serta mentransmisikan sumbersumber ekonomi masyarakat menjadi penerimaan pemerintah.

Kesejahteraan merupakan perwujudan dari cita-cita pembangunan ekonomi suatu negara dan salah satu tujuan dari pemungutan pajak. Bagi bangsa Indonesia, kesejahteraan sudah sangat jelas diatur tersendiri dalam UUD 1945 Pasal 33. Pembangunan merupakan bentuk kristalisasi ide dan kreativitas negara dalam rangka mencapai kesejahteraan hidup masyarakat.

Ide dan kreativitas tersebut meliputi segala konsep dan program pembangunan yang merupakan reprensentasi kehendak masyarakat dalam rangka mencapai kemakmuran. Pengurangan kemiskinan, pemerataan pembangunan, peningkatan gizi, kesempatan kerja yang luas, dan peningkatan kualitas pendidikan merupakan beberapa bentuk kesejahteraan yang diinginkan masyarakat.

Ada beberapa alasan mengapa kebutuhan akan perpajakan itu timbul. Alasan pertama adalah bahwa sistem administrasi perlu menyediakan barang dan jasa kolektif. 
Alasan kedua, sistem administrasi perlu mengambil langkah-langkah untuk mengatasi kegagalan-kegagalan tertentu dari mekanisme pasar sehingga langkah-langkah yang diambil itu mencerminkan mekanisme perencanaan. Alasan ketiga, berkaitan dengan pemerataan dalam pembagian pendapatan. Alasan keempat, adanya ketidaksempurnaan pasar. Ada sumber lain dari pengeluaran yang dilaksanakan oleh sistem administrasi yaitu yang berkaitan dengan campur tangan sistem administrasi yang timbul dari kegagalan mekanisme perencanaan pasar.

Memberikan pengertian pajak akan berkaitan dengan masalah yang dapat menjelaskan fungsi dari pajak dengan keyakinan bahwa pengartian tersebut mencakup segi-segi pokok yang terkandung di dalamnya. Sistem administrasi melakukan penarikan pajak bukan semata-mata untuk memperoleh dana akan tetapi juga dapat mengawasi pengeluaran dari sistem kegiatan sosial sehingga permintaan konsumsi dan investasi dari sistem administrasi ditambah dengan permintaan konsumsi dan investasi dari sistem kegiatan sosial akan sama dengan pendapatan pada tingkat kesempatan kerja tertentu. ujuan dari perpajakan adalah untuk menekan konsumsi dan investasi dari sistem kegiatan sosial sehingga sistem administrasi dapat menyediakan barang dan jasa publik, sosial atau kolektif dan dapat memberikan subsidi kepada golongan miskin tanpa menimbulkan inflasi dan kesukaran dalam neraca pembayaran.

Fungsi pokok dari perpajakan adalah untuk menekan berbagai permintaan akan kapasitas produktif dari sistem kegiatan sosial. Dengan demikian, perpajakan mempunyai tujuan lain, di samping sebagai sumber pendapatan negara. Perpajakan yang eifisien dilaksanakan dengan suatu cara yang dapat membantu pembagian pendapatan yang lebih merata, dapat membantu untuk memberikan dorongan tingkat pertumbuhan ekonomi dan memperkuat kebijaksanaan pengeluaran anggaran yang dilaksanakan oleh sistem administrasi.

\section{Tujuan Kegiatan}

Setelah mengikuti Pelatihan Perpajakan ini, peserta diharapkan memiliki pengetahuan untuk:

a. Peserta dibekali konsep yang sederhana bagaimana merumuskan Perpajakan yang baik.

b. Peserta mampu mengidentifikasi faktorfaktor yang mendukung dan tidak mendukung kelayakan bisnis dari berbagai aspek yang akan dievaluasi.

c. Peserta mampu membuat proyeksi keuangan yang sederhana dan terukur berdasarkan asumsi-asumsi dasar yang dibangun dari berbagai aspek.

\section{Manfaat Kegiatan}

Pelatihan Perpajakan ini akan mengajarkan kepada meraka bahwa kewajiban perpajakan ini adalah berlaku untuk semua wajib pajak, baik wajib pajak dalam negeri maupun wajib pajak luar negeri.

\section{Target}

Kehadiran BUMDes sangat penting peranannya sebagai wadah untuk membangun sebuah desa, dengan adanya BUMDes maka pengelolaan bisnis di sebuah desa akan berjalan maksimal karena ada pendampingan dan pengawasan dari BUMDes. Namun hal itu tidak akan terwujud apabila BUMDes sendiri tidak memiliki kemampuan dan sarana yang memadai. Sudah banyak kasus BUMDes yang akhirnya hanya sekedar nama tanpa ada aktifitas dikarenakan kemampuan manajerial yang buruk.

Selain itu pula kini pemerintah tengah menggulirkan program Dana Desa dimana tiap desa diberikan sejumlah dana yang bertujuan untuk pengembanga potensi dan roda perekenomian di desa. Dengan adanya BUMDes maka diharapkan investasi yang ditanamkan di desa tersebut sesuai target dan dapat mengangkat kesejahteraan warga di desa tersebut. Namun pada pelaksanaannya masih banyak BUMDes yang gagal melaksanakan tujuan program tersebut, selain 
karena kemampuan yang tidak memadai namun juga terjadi penyimpangan yang dikarenakan penyalahgunaan dana tersebut.

Oleh karena itu diperlukan ada pelatihan BUMDes agar jajaran yang mengisi BUMDes tersebut memikiki kemampuan dan pengetahuan yang memadai sehingga dapat menjalankan BUMDes dengan baik. Selain kemampuan teknikal seperti akuntansi dan manajerial, pelatihan karakter juga diperlukan agar melahirkan pengelola staf BUMDes yang jujur.

Selain itu tumbuh dan berkembangnya Bumdes di Kabupaten Bintan ini katena menjadi salah satu tujuan wisata baik kuliner, maupun wisata belanja. Akibatnya perkembangan disektor ini pun menjadi surga bagi Bumdes untuk terus mengembangkan produknya mulai dari industri makanan dan minuman, home industry dan berbagai varian produk lainnya khas Kabupaten Bintan. Apabila geliat di sektor Bumdes ini terus meningkat, maka akan berbanding dengan peningkatan PAD baik dari sektor jasa maupun dari sektor lainnya.

Dalam pengembangan Bumdes persoalan yang paling sering muncul adalah masalah permodalan dan pemasaran. Permodalan dasar utamanya yaitu karena sistem akuntansi yang belum diterapkan, dikarenakan Bumdes banyak mengalami kendala dalam pembuatannya, yaitu minimnya ilmu yang dimiliki tentang sistem akuntansi dan hal itu merupakan kendala sebagian besar yang dihadapi oleh beberapa Bumdes, dengan kata lain, tidak mengerti harus bagaimana, apa yang harus dipersiapkan, dan bagaimana menerapkannya, sehingga yang menjadi target dalam kegiatan ini adalah para pelaku usaha yang tergabung dalam kelompok usaha ekonomi masyarakat yang menggunakan modal kerjanya dari penyetoran dana desa yang saat ini dikelola oleh setiap desa yang ada di setiap kecamatan.

\section{METODE}

Metodologi pelaksanaan dalam pengabdian pada masyarakat ini dibagi menjadi 3 (tiga) tahap yaitu tahap awal, tahap pelaksanaan dan tahap akhir. Pada tahap awal dilaksanakan kunjungan ke Dinas Pemberdayaan Masyarakat Kabupaten Bintan yang menangani Bumdes serta meminta data yang diperlukan terkait dengan operasionalisasi Bumdes, selanjutnya melakukan koordinasi dengan Tenaga Ahli Kabupaten Bintan khususnya yang membidangi pengembangan ekonomi desa. Pada rencana awal pelaksanaan dilakukan dalam bentuk tatap muka mengingat pada pelatihan perpajakan ini akan efektif apabila dilakukan dalam bentuk tatap muka, dimana pelatihan ini akan dilaksanakan di aula kantor Dinas Pemberdayaan Masyarakat Desa Kabupaten Bintan pada pertengahan juni 2020. Namun dengan melihat perkembangan Covid 19 yang masih belum mereda maka diputuskan untuk menunda sampai akhir agustus 2020, dan ternyata Covid 19 juga masih belum mereda, sehingga pelatihan secara tatap muka tidak dapat dilaksanakan, dan dari audiensi dengan pihak Dinas Pemberdayaan Masyarakat Desa maka diputuskanlah untuk melaksanakan pelatihan perpajakan ini secara daring dimana pelatihan perpajakan tersebut dilaksanakan pada minggu keempat di bulan Agustus 2020 yang akan diikuti sebanyak 30 orang pengurus Bumdes se Kabupaten Bintan.

\section{HASIL DAN PEMBAHASAN}

Pengabdian pada masyarakat pada Badan Usaha Milik Desa (BUMdes) pelaksanaannya semula akan dilakukan secara offline yaitu mengumpulkan para pengurus Bumdes yang ada di Kabupaten Bintan, namun mengingat situasi dan kondisi saat ini yang masih belum kondusif di mana sampai dengan akhir bulan juli Kabupaten Bintan turun status dari zona hijau menjadi zona merah setelah ada tambahan pasien yang positif Covid 19 dalam sepekan terkhir, berdasarkan laporan jubir gugus tugas percepatan penanganan Covid 19 Kabupaten 
Bintan dr. Gama. Antara. Dengan demikian pelaksanaan kegiatan "Pelatihan Perpajakan bagi Badan Usaha Milik Desa (BUMDes)" dilaksanakan secara daring (webinar) pada hari selasa, tanggal 25 Agustus 2020 yang diikuti oleh 30 Pengurus Bumdes, dan dihadiri juga oleh Kabid pada Dinas Pemberdayaan Masyarakat dan Desa Provinsi Kepulauan Riau, Tenaga Ahli Pemberdayaan Ekonomi Desa Provinsi Kepulauan Riau, dan acara dibuka oleh Ketua LP3M Universitas Maritim Raja Ali Haji.

Dari pelaksanaan pelatihan tersebut, beberapa pertanyaan yang paling banyak ditanyakan adalah :

a. Bagaimana pengenaan pajak atas transaksi sewa, yaitu antara sewa tanah dan bangunan serta sewa selain tanah dan bangunan? Sewa bangunan dikenakan dua jenis pajak yaitu PPh pasal 4 ayat 2 dan PPN. Dalam penerapannya berlaku ketentuan sebagai berikut :

1. Atas pembayaran biaya sewa bangunan oleh suatu perusahaan, pemilik tanah dan bangunan wajib penerbitkan faktur pajak atas pungutan PPN sebesar 10\% x seluruh biaya sewa atas transaksi sewa bangunan tersebut.

2. Apabila pemilik tanah merupakan PKP, maka biaya sewa yang dibayarkan utuk satu periode/ tahun tidak termasuk pajak PPN. Namun apabila pemilik tanah bukan PKP, maka biaya sewa adalah uang sewa ditambah PPN yang telah dibayarkan. Dengan kata lain biaya sewa yang dibayarkan pihak penyewa sudah mengandung unsur PPN di dalamnya.

3. Selain PPN penyewaan bangunan juga dikenakan $\mathrm{PPh}$ pasal 4 ayat 2 sebesar $10 \%$ dari seluruh biaya sewa. Pihak penyewa wajib memberi bukti pemotongan Pph pasal 4 ayat 2 ke pemilik tanah dan bangunan tersebut.

4. Pajak atas sewa bangunan merupakan jenis pajak yang bersifat final, hal ini sebagaimana tertullis dalam UU no. 7
Tahun 1983 tentang Pajak

Penghasilan.

Ketentuan untuk potongan pajak atas sewa bangunan diantaranya :

1. Apabila penyewa adalah badan pemerintah, subjek pajak badan dalam negeri, penyelenggara kegiatan, bentuk usaha tetap, kerjasama operasi, perwakilan perusahaan luar negeri dan orang pribadi yang ditetapkan DJP maka $\mathrm{PPh}$ terutang wajib dipotong oleh penyewa dan penyewa wajib memberikan bukti potong kepada yang menyewakan/ yang menerima penghasilan.

2. Apabila penyewa adalah orang pribadi / bukan subjek pajak penghasilan maka PPh terutang wajib dibayar sendiri oleh pihak yang menyewakan.

b. Bagaimana pengenaan pajak atas setoran modal, baik berupa aset maupun berupa uang tunai dari kepala desa?

Setoran modal atas saham yang selama ini lazim disebutkan dalam akta pendirian perusahaan dalam bentuk Perseroan Terbatas (PT) atau Perseroan Komanditer (CV) yang terdiri dari saham adalah setoran modal tunai. Atas kejadian tersebut belum terdapat penghasilan yang dikenakan pajak baik bagi pihak yang menerima maupun penyetor modal. Namun, apabila setoran modal dilakukan dalam bentuk tanah dan bangunan maka pihak penyetor modal tersebut wajib melunasi pajak penghasilan bersifat final atas pengalihan hak atas tanah. Berdasarkan penelusuran pada UU Perseroan Terbatas dan ketentuan perpajakan dapat disimpulkan bahwa pajak penghasilan final yang dibayar pemilik modal bukan merupakan pajak atas setoran modal tetapi merupakan pajak atas penghasilan yang diperoleh dari selisih nilai perolehan dengan harga pasar tanah dan bangunan yang mekanisme pengenaan pajaknya bersifat final dan dikenakan pada saat pengalihan tanah dan bangunan kepada pihak lain.

c. Apakah semua transaksi yang terjadi harus dikenakan PPN? Dan bagaimana 
mekanisme pemungutan dan pelaporannya?

PPN adalah pajak yang dikenakan atas konsumsi dalam negeri oleh Wajib Pajak Orang Pribadi, Badan, dan Pemerintah. Dalam penerapannya, Badan atau perorangan yang membayar pajak ini tidak diwajibkan untuk menyetorkan langsung ke kas negara, melainkan lewat pihak yang memotong PPN.

Pajak Pertambahan Nilai bersifat objektif, tidak kumulatif, dan merupakan pajak tidak langsung. Subjek pajaknya terdiri dari Pengusaha Kena Pajak (PKP) dan non PKP, harus dipahami subjek pajak ini berbeda dengan Wajib Pajak. Subjek pajak belum memiliki kewajiban untuk membayar pajak sedangkan Wajib Pajak sudah memiliki kewajiban untuk membayar pajak.

Barang atau Jasa yang Dikenakan Pajak Pertambahan Nilai (PPN)

1. Penyerahan Barang Kena Pajak (BPK) dan Jasa Kena Pajak (JKP) di dalam daerah Pabean yang dilakukan oleh pengusaha.

2. Impor Barang Kena Pajak.

3. Pemanfaatan barang kena pajak tidak berwujud dari luar daerah pabean di dalam daerah pabean.

4. Pemanfaatan jasa kena pajak dari luar daerah pabean di dalam daerah pabean.

5. Ekspor Barang Kena Pajak berwujud atau tidak berwujud dan ekspor Jasa Kena Pajak oleh Pengusaha Kena Pajak (PKP).

6. Kegiatan Membangun Sendiri bangunan dengan luas lebih dari 200m2 yang dilakukan di luar lingkungan perusahaan dan/atau pekerjaan oleh Orang Pribadi atau Badan yang hasilnya digunakan sendiri atau pihak lain.

7. Penyerahan aktiva yang menurut tujuan semula tidak untuk diperjualbelikan, sepanjang pajak masukan yang dibayar pada saat perolehan aktiva tersebut boleh dikreditkan.

Barang atau Jasa yang Tidak Dikenakan Pajak Pertambahan Nilai (PPN)

1. Barang hasil pertambangan atau pengeboran (minyak mentah, asbes, batu bara, gas bumi, dan lain-lain).
2. Barang Kebutuhan Pokok (beras, jagung, susu, daging, kedelai, sayuran, dan lainnya).

3. Makanan dan minuman yang disajikan di rumah makan atau restoran.

4. Uang dan emas batangan.

5. Jasa pelayanan medis, pelayanan sosial, jasa keuangan, asuransi, pendidikan dan sebagainya.

d. Bagi Bumdes yang saat ini masih belum menjalankan kegiatannya, bagaimana dengan kewajiban perpajakannya?

Kewajiban yang harus dilaksanakan setelah memperoleh NPWP oleh Wajib Pajak:

1. Kewajiban sehubungan dengan Pajak Penghasilan (PPh)

a. SPT Masa, yaitu pelaporan pelaksanaan withholding tax, yaitu: PPh Pasal 21, PPh Pasal 22, PPh Pasal 23, PPh Pasal 26, PPh Pasal 15, dan PPh Pasal 4 ayat (2). Ada dua pendapat tentang pelaporlan withholding tax ini, pertama : ada atau tidak ada objek, wajib membuat SPT. Pendapat kedua, dilaporkan jika ada objek saja. Silakan pilih mana yang lebih nyaman.

b. SPT Tahunan, yaitu pelaporan pelaksaan kewajiban perpajakan selama satu tahun penuh, yaitu PPh badan atau PPh Orang Pribadi, dan PPh Pasal 21.

Khusus untuk perusahaan yang belum berjalan, SPT Tahunan baik PPh Badan maupun PPh Pasal 21 diisi "NIHIL", ditandatangani, dan dibuatkan "Surat Penyataan" bahwa perusahaan belum berjalan atau belum beroperasi. Saya pikir, perusahaan yang belum beroperasi tidak memiliki kewajiban menyampaikan SPT Masa.

2. Kewajiban sehubungan dengan Pajak Pertambahan Nilai/Pajak Penjualan atas Barang Mewah (PPN \& PPnBM), yaitu SPT Masa PPN. Surat Pemberitahuan (SPT) adalah surat yang oleh Wajib Pajak digunakan untuk melaporkan penghitungan dan/atau pembayaran pajak, objek pajak dan/atau bukan objek pajak, dan/atau harta dan kewajiban 
sesuai dengan ketentuan peraturan perundang-undangan perpajakan. Surat Pemberitahuan Masa (SPT Masa) adalah Surat Pemberitahuan untuk suatu Masa Pajak. Masa Pajak adalah jangka waktu yang menjadi dasar bagi Wajib Pajak untuk menghitung, menyetor, dan melaporkan pajak yang terutang dalam suatu jangka waktu tertentu. Umumnya satu masa sama dengan satu bulan kalender.

e. Bagaimana penerapan tarif $\mathrm{PPh}$ Badan, apakah tarif tersebut penerapannya bagi Bumdes sama dengan wajib pajak badan lainnya seperti PT? atau apakah ada tarif khusus untuk Bumdes?

Pada dasarnya BUMDes merupakan suatu Badan Usaha, sama halnya dengan Badan Usaha lain seperti PT atau CV. Hanya saja, BUMDes dimiliki oleh sebuah desa. BUMDes sendiri tidak ada aturan yang menjelaskan BUMDes harus membuat NPWP dan seandainya membuat NPWP. Akte pendirian BUMDes seperti apa? Ketika BUMDes berkeinginan membuat NPWP akte pendirian BUMDes menggunakan peraturan desa yang telah diterbitkan atau disahkan.

Selama itu, kita ketahui bahwa program pemerintah tidak dikenakan pajak. Namun, jika kita pahami penjelasan objek pajak yang dapat diartikan suatu transaksi (biasanya sumber pendapatan) yang menurut peraturan perpajakan tergolong sebagai transaksi yang harus dikenai pajak. Pendapatan dari suatu yayasan yang berasal dari sumbangan dan hibah bukan merupakan objek pajak. BUMDes memiliki kegiatan operasional yang mana dari kegiatan tersebut mampu menghasilkan keuntungan. Sehingga, BUMDes telah memenuhi syarat sebagai objek pajak.

Subjek pajak badan menjelaskan pasal 2 ayat (1) UU PPh adalah sekumpulan orang dan/atau modal yang merupakan kesatuan baik yang melakukan usaha maupun yang tidak melakukan usaha yang meliputi perseroan terbatas, perseroan komanditer, perseroan lainnya, badan usaha milik negara atau badan usaha milik daerah dengan nama dan dalam bentuk apa pun, firma, kongsi, koperasi, dana pensiun, persekutuan, perkumpulan, yayasan, organisasi massa, organisasi sosial politik, atau organisasi lainnya, lembaga, dan bentuk badan lainnya termasuk kontrak investasi kolektif dan bentuk usaha tetap.

Dalam hal pengenaan pajak untuk BUMDes, jenis pajak Badan Usaha yang harus dibayarkan adalah $\mathrm{PPh} 21, \mathrm{PPh}, 23$, PPh Pasal 4 Ayat (2), serta PPN apabila sudah dikukuhkan sebagai Pengusaha Kena Pajak

\section{Rencana Tahap Berikutnya}

Dari hasil pelatihan tersebut diperoleh gambaran bahwa sebagian besar pengurus Bumdes masih sangat sedikit pemahaman dalam bidang perpajakan sementara kegiatan-kegiatan bumdes cukup banyak. Dari gambaran tersebut dapat disimpulkan bahwa pemahaman para pengurus bumdes dalam bidang perpajakan kemungkinan besar di kabupaten lainnya di Provinsi Kepulauan Riau adalah sama dengan gambaran yang ada di kabupaten bintan. Oleh karenanya rencana pengabdian kepada masyarakat pada tahap berikutnya adalah :

a. Memberikan pelatihan perpajakan bagi pengurus bumdes di seluruh kabupaten yang ada di provinsi kepulauan riau.

b. Dari jumlah desa yang ada di kepri sebanyakj 275 desa ternyata belum semuanya memiliki Bumdes, sehingga perlu didorong pada setiap desa agar segera mendirikan Bumdes, hal ini dapat dilakukan dengan bekerja sama dengan pihak-pihak terkait terutama Dinas Pemberdayaan Masyarakat dan Desa baik tingkat provinsi maupun tingkat kabupaten

\section{KESIMPULAN}

1. Kegiatan pengabdian yang akan dilaksanakan berupa pelatihan perpajakan yang akan dilaksanakan sebagai bentuk tambahan pengetahuan di bidang perpajakan pada setiap Badan Usaha Milik Desa (Bumdes) di Kabupaten 
Bintan, yaitu sebanyak 32 Bumdes yang sudah dibentuk di setiap desa dan 24 Bumdes yang pada tahun buku 2019 telah menyumbangkan Pendapatan Asli Desa (PADes).

2. Dengan mengikuti Pelatihan Perpajakan ini para peserta akan dibekali dengan konsep dasar bagaimana memahami siapa wajib pajak, apa yang menjadi objek pajak, dan bagaimana melakukan penghitungan transaksi-transaksi yang ada unsur pajaknya.

3. Badan Usaha Milik Desa (BUMDes) merupakan jenis pajak Badan Usaha yang seluruh atau sebagian besar modalnya dimiliki oleh desa melalui penyertaan secara langsung yang berasal dari kekayaan desa yang dipisahkan guna mengelola aset, jasa pelayanan, dan usaha lainnya untuk sebesar-besarnya kesejahteraan masyarakat desa.

4. Pada dasarnya BUMDes merupakan suatu Badan Usaha, sama halnya dengan Badan Usaha lain seperti PT atau CV. Hanya saja, BUMDes dimiliki oleh sebuah desa. Oleh karena itu, BUMDes memiliki kedudukan yang sama sebagai Wajib Pajak berbentuk Badan Usaha.

5. Kegiatan ini dilaksanakan secara online melalui aplikasi zoom pada tanggal 25 Agustus 2020 yang diikuti oleh 30 peserta dari Pengurus Bumdes se Kabupaten Bintan.

\section{DAFTAR PUSTAKA}

Ghozali I. 2016. Aplikasi Analisiss Multivariate dengan Program SPSS. Vol.
Cetakan ke VIII: Badan Penerbit Universitas Diponegoro

Mardiasmo. 2011. Perpajakan. Edisi Revisi 2011. Yogyakarta: Andi.

Rahayu. 2010. Perpajakan Indonesia-Konsep dan Aspek Formal. Graha Ilmu. Jakarta

Resmi S. 2008. Perpajakan Teori dan Kasus. Jakarta : Salemba Empat.

Rivai V. 2013. Commercial Bank Management: Manajemen Perbankan Dari Teori Ke Praktik. Edisi 1.Cetakan1. Jakarta: Rajawali Pers.

Samudra A. 2015. Perpajakan Indonesia. Keuangan, Pajak dan Retribusi Daerah. Jakarta: Rajawali Pers, 2015.

Sugiyono. 2016. Metode Penelitian Kombinasi (Mixed Methods). Cetakan ke 8. Penerbit Alfabeta Bandung

Sukrisno A, \& Trisnawati E. 2014. Akuntansi Perpajakan.Edisi 3. Jakarta: Salemba Empat.

Supramono, D. 2010. Perpajakan Indonesia. Yogyakarta: CV. ANDI

Undang-undang Republik Indonesia No 28 tahun 2007 tentang Perubahan Ketiga atas Undang-Undang No 6 tahun 1983 tentang Ketentuan Umum dan Tata Cara Perpajakan

Undang-undang Republik Indonesia No 36 tahun 2008 tentang Perubahan Ketiga atas Undang-Undang No 7 tahun 1983 tentang Pajak Penghasilan

Waluyo. 2011.Perpajakan Indonesia (Buku Satu Edisi 10). Jakarta: Salemba Empat. www.iaiglobal.or.id (accessed Juli 2020) www.pajak.go.id (accessed Juli 2020) 